\title{
Physio-chemical characteristics and bacterial diversity in copper mining wastewater based on 16S rRNA gene analysis
}

\author{
Islam-ud-din ${ }^{1 *}$, Sardar Khan ${ }^{2}$, Abd El-latif Hesham ${ }^{3}$, Ayaz Ahmad ${ }^{4}$, Su Houbo ${ }^{1}$ and Cang \\ Daqiang ${ }^{5}$
}

${ }^{1}$ School of Civil and Environmental Engineering, University of Science and Technology Beijing, Xueyuan Lu 30, Beijing 100083, China.

${ }^{2}$ Department of Environmental Science, University of Peshawar, Peshawar 25120, Pakistan.

${ }^{3}$ Genetics Department, Faculty of Agriculture, Assiut University, Assiut, Egypt.

${ }^{4}$ Graduate University of Chinese Academy of Sciences, Beijing 100039, China

${ }^{5}$ School of Metallurgical and Ecological Engineering, University of Science and Technology, Beijing, Xueyuan Lu 30, Beijing 100083, China.

Accepted 30 September, 2010

The effects of seasonal change in temperature on the chemical compositions of water and bacterial diversity in copper mining wastewater reservoir (CMWR) located in Jiangxi province, China, was investigated. Wastewater samples were collected collected in December 2008 and May 2009 from different points of CMWR and analyzed for anions, heavy metals, and microbial community structure using standard procedures. Most of the parameters exceeded the limits set by the Chinese government. However, the concentrations of some selected parameters such as $\mathrm{pH}, \mathrm{BOD}, \mathrm{DO}$, and DOC and heavy metals were significantly $(P=0.05)$ varied and exhibited a reduction from the inlet to the outlet of CMWR. Bacterial diversity was studied by the combined polymerase chain reaction-denaturing gradient gel electrophoresis (PCR-DGGE) and cloning approach. The PCR-DGGE profiles showed the presence of 10 common bands in the seasonal samples of the reservoir indicating the high similarities among the bacterial populations existing during the two seasons. Furthermore, the DGGE profiles also evidenced the existence of some unique bands suggesting that the differences in bacterial diversity may be caused by the different environmental conditions. 22 major bands from the DGGE profiles were further reamplified, cloned, and sequenced. The results of sequencing analysis indicated the presence of Rheinheimera sp., Acidithiobacillus ferrooxidans, Afipia sp. and Burkholderia sp. as the dominant bacterial species in the CMWR samples. The Afipia sp. and Burkholderia sp. were found in summer samples only while most of the other species were common in both the seasons. Finally, the Copper mine wastewater was deficient in nutrients but enriched with the bacterial diversity of the extremophiles.

Key words: Copper mining, heavy metals, bacterial diversity, polymerase chain reaction-denaturing gradient gel electrophoresis (PCR-DGGE), 16S rRNA.

\section{INTRODUCTION}

Environmental contamination with heavy metals, origi-nating from both natural and anthropogenic activities, has become a global concern due to its adverse effects on vegetation cover, food crop quality, human health, water resources and microbial diversity, and functionality in the environment (Guo et al., 2009; Khan et al., 2008). Mining is one of the major anthropogenic activities resulting in the release of 
heavy metals into the environment 7892 Afr. J. Biotechnol.

(Passariello et al., 2002; Wang et al., 2009). Copper mining (CM) generates a huge quantity of wastes possessing high concentrations of heavy metals (Yin et al., 2008). Furthermore, the wastewater generated from the $\mathrm{CM}$ activities is acidic in nature and leads to not only the pollution of surface water and groundwater resources but also deteriorates the bacterial community structure in the aquatic ecosystems (Foster et al., 2008).

Typically, the bacterial community structure is charac-terized by numerous factors including $\mathrm{pH}$, temperature, concentrations of oxygen and carbon dioxide, nutrients, electron acceptors, carbon contents, and heavy metals etc (Compton et al., 2004; Fey and Conrad, 2000; Khan et al., 2007; Kopke et al., 2005; Zhou et al., 2002). The mining wastewater exhibits a complex environment and displays the unique geochemical properties (Feris et al., 2004). Despite their distinctive characteristics, the mining wastewater possesses various bacterial species such as Acidithiobacillus ferrooxidans, Acidithiobacillus thiooxidans, Acidithiobacillus caldus and Leptospirillum ferrooxidans and common prokaryotic chemolithotrophs (Xiao et al., 2009). Both cultural and non-cultural based techniques have been employed by researchers to investigate the bacterial community structure and the diversification in the environmental samples. Cultural-based analysis is not considered an appropriate technique to study the charac-terization of microbial communities (DeLong, 1992).

In order to investigate the relationship between the chemistry of mining wastewater and bacterial community structure changes, it is essential to study the bacterial diversity by using the advanced molecular techniques such as polymerase chain reactiondenaturing gradient gel electrophoresis (PCR-DGGE). This method has recently been utilized to investigate microbial diversity. DGGE offers a very good analytical opportunity to overcome the limitations and shortcomings associated with the culture based techniques and moreover, it aids in discerning the mechanism involved during the microbial diversity and functionality in the environment (Malik et al., 2008). The responses of bacterial community in aquatic bodies, dealing with the heavy metal contaminations, pre-sent a very appropriate model for the ecological studies in assessing the adverse impacts of environmental characteristics. However, during the bacterial community study, other environmental factors are also considered

${ }^{*}$ Corresponding author. E-mail: idd_nwa2000@yahoo.com. Tel: 86-13501319042. Fax: 86-10-62333893.
Abbreviations: CM, Copper mining; CMWR, copper mining wastewater reservoir; PCR-DGGE, polymerase chain reactiondenaturing gradient gel electrophoresis; COD, chemical oxygen demand; DOC, dissolved organic carbon; DO, dissolved oxygen; BOD, biological oxygen demand; LB, Luria-Bertani; BLAST, Basic Local Alignment Search Tool.

such as $\mathrm{pH}$, anions, and heavy metals.

Previously, several researchers have studied the mining water composition and the variability in the micro-bial community structure (Foster et al., 2008; Wang et al., 2009). However, further research work is needed to discern the geochemical characteristics of mining waste-water and the relationship among the composition of wastewater, bacterial distributions, and diversity. In the present work, the seasonal change in CM's wastewater chemistry and bacterial diversity was investigated by using PCR-DGGE with subsequent cloning techniques.

\section{MATERIALS AND METHODS}

\section{Site description}

The study site (Yongping Copper Mine) is located in Shangrao City, Jiangxi Province, in the southeast of China. It is an open pit type mine owned by Jiangxi Copper Company limited. The mine wastewater is collected in a reservoir with total area of about $1 \mathrm{~km}^{2}$ and $10 \mathrm{~m}$ depth. The water has brownishred color with no visible life.

\section{Samples collection}

Water samples were collected in winter (December, 2008) and summer (May, 2009) from different spots near inlet, middle, and outlet of the Copper Mining Wastewater Reservoir (CMWR). Samples were taken in triplicates from each spot 1 - 3 m deep by electric pump. Samples for chemical oxygen demand (COD), dissolved organic carbon (DOC), sulfides, and heavy metals analyses were treated on the spot according to standard methods (APHA et al., 1998). For bacterial community study, 10 to $15 \mathrm{~L}$ water sample from each location was filtered on the spot using filtration system $(0.22 \mu \mathrm{m})$ provided with the kit (UltraClean ${ }^{\mathrm{TM}}$ Water DNA Isolation Kit, MO BIO Laboratories, Inc., CA). Both the filters and water samples were transported aseptically and stored at $4{ }^{\circ} \mathrm{C}$ for further analyses.

\section{Physiochemical analysis}

Temperature, $\mathrm{pH}$, and dissolved oxygen (DO) were determined in situ using the respective electrodes. Samples were prepared for measuring biological oxygen demand $\left(\mathrm{BOD}_{5}\right)$ within $24 \mathrm{~h}$ and measured by membrane electrode method. Sulfate concentrations were measured turbidimetrically, and sulfide was measured iodometrically (APHA et al., 1998). Dissolved organic carbon (DOC) was determined with Liqui TOC II (Elementar Analysensysteme GmbH Donaustrasse 7 D-63452 Hanau, Germany) (Liu and Sheu, 2003). Chemical oxygen demand (COD) was measured photometrically (Spectroquant TR420 and Nova60, Merck, Germany) 
(Ehlers and Rose 2005). Dissolved heavy metals were analyzed by atomic absorption spectrometry (AA-6300, Shimadzu, Japan).

\section{DNA extraction and PCR amplification}

The genomic DNA was extracted directly by using UltraClean ${ }^{\mathrm{TM}}$ Water DNA Isolation Kit $(0.22 \mu \mathrm{m})$ (MO BIO Laboratories, Inc., CA) template and re-amplified using the primers 954F/1369R (without GC clamp).

\section{Cloning and sequencing of DGGE fragments}

The re-amplified PCR products (using primers 954F/1369R without GC clamp) were gel purified and extracted with an EZ Spin Column DNA Gel Extraction Kit (Biotechnology Department Bio Basic Inc. Islam-ud-din et al. 7893

(BBI), Ontario, Canada). Purified fragments were ligated with pBS-T II vector kit (Tiangen Biotech Co., Ltd. Beijing) according to the manufacturer's protocol. After transferring to Escherichia coli $\mathrm{DH} 5 \mathrm{a}$ competent cells and culturing, the transformants were selected by blue-white selection on Luria-Bertani (LB) agar plates containing 40 $\mu \mathrm{l}$ of the 5-bromo-4-chloro-3-indolyl $\beta$-D-galactopyranoside (X-Gal) solution $(20 \mathrm{mg} / \mathrm{ml}), 20 \mu \mathrm{l}$ of $100 \mathrm{mM}$ IPTG and $20 \mu \mathrm{l}$ ampicillin (50 $\mathrm{mg} / \mathrm{ml}$ ). Cloned inserts were amplified by PCR with plasmid-vector specific primers M13F (5-GTAAAACGACGGCCAG-3) and M13R (5-CAGGAAACAGCTATGAC-3). Clones were sequenced with an automated sequencer (Sunbiotech Company, Beijing, China).

\section{Phylogenetic tree analysis}

Partial 16S rRNA sequences were compared with sequences in the GenBank database using the Basic Local Alignment Search Tool (BLAST) search tool for the identification of closely related sequences. Phylogenetic tree was constructed using MEGA version 4.0 by the neighbor-joining algorithm, and the Jukes-Cantor distance estimation method with bootstrap analyses for 1000 replicates was performed.

\section{Nucleotide sequence accession numbers}

The nucleotide sequences of partial 16S rRNA genes, reported in this study, have been deposited in the GenBank database under accession numbers: GU979829-GU979850.

\section{Data analysis}

All analyses were performed in triplicate and the data were statistically analyzed using the statistical package SPSS 17.0. The measures were expressed in terms of mean and standard deviation of triplicate. Statistical significance was computed using Duncan's multiple range test and paired-samples t-test, with a significance level of $\mathrm{P}<0.01$.

\section{RESULTS AND DISCUSSION}

\section{Physio-chemical parameters}

Detection system (Bio-Rad Laboratories, Hercules, CA.) according to the manufacturer's instruction. Six percent $(6$ (w/v) polyacrylamide gel (37.5:1) with a denaturant gradient from 35 to $60 \%$ $(100 \%$ denaturants consisting of $40 \%$ [v/v] formamide and $7 \mathrm{M}$ urea) (Muyzer et al., 1995) was used in 1× TAE buffer for analyzing fragments amplified using 954F (GC)/1369R. The DGGE gel was run at $60^{\circ} \mathrm{C}$, first for $10 \mathrm{~min}$ at $20 \mathrm{~V}$ and then for $8 \mathrm{~h}$ at $100 \mathrm{~V}$. Subsequently, the gel was stained with SYBR Gold for $30 \mathrm{~min}$, and gel images were obtained using the G:Box (Syngene, Synoptics Limited. England). After the gel image analysis with Quantity One software (Bio-rad Laboratories), major bands were excised from the gel, and stored in $30 \mu \mathrm{TE}$ buffer at $4^{\circ} \mathrm{C}$ overnight. Then after centrifugation for few seconds, $2 \mu \mathrm{l}$ of supernatant was used as
Table 1 summarizes the average values of physio-chemical parameters in the wastewater samples collected from inlet, middle and outlet of the reservoir. In the wastewater samples, the temperature values exhibit a big variation from winter to summer but with a little change from inlet to outlet of the CMWR. However, the $\mathrm{pH}$ values demonstrate both the seasonal as well as the spatial changes, ranging from $2.10-2.60$ and reaches beyond the permissible limit (6 to 9 ) set for industrial and sewage 
wastewater (MEP, 2002). These findings are quite consistent with those reported by Chen et al. (2008). The analysis of variance (ANOVA) analyses indicated that the $\mathrm{pH}$ values in the outlet wastewater samples are not 7894 Afr. J. Biotechnol. significantly higher $(P<0.01)$ than that in the inlet of the CMWR, indicating that the $\mathrm{pH}$ has not been greatly affected by impounding the $\mathrm{CM}$ wastewater into the reservoir. A slight variation (13.6\%) in the $\mathrm{pH}$ values is

Table 1 Physio-chemical properties of the CM wastewater collected from the reservoir (Average values for winter and summer).

\begin{tabular}{|c|c|c|c|c|c|c|c|c|c|c|}
\hline \multirow{2}{*}{ Location } & \multicolumn{2}{|c|}{ Temperature $\left({ }^{\circ} \mathrm{C}\right)$} & \multicolumn{2}{|c|}{$\mathrm{pH}$} & \multirow{2}{*}{$\begin{array}{c}\mathrm{DO} \\
(\mathrm{mg} / \mathrm{l})\end{array}$} & \multirow{2}{*}{$\begin{array}{c}\text { BOD } \\
(\mathrm{mg} / \mathrm{l})\end{array}$} & \multirow{2}{*}{$\begin{array}{l}\mathrm{COD} \\
(\mathrm{mg} / \mathrm{l})\end{array}$} & \multirow{2}{*}{$\begin{array}{c}\mathrm{DOC} \\
(\mathrm{mg} / \mathrm{l})\end{array}$} & \multirow{2}{*}{$\begin{array}{l}\mathrm{SO}_{4}{ }^{2-} \\
(\mathrm{mg} / \mathrm{l})\end{array}$} & \multirow{2}{*}{$\begin{array}{c}\text { Sulfides } \\
(\mathrm{mg} / \mathrm{l})\end{array}$} \\
\hline & Dec & May & Dec & May & & & & & & \\
\hline Inlet & 5 & 23 & 2.3 & 2.1 & 3.8 & 3.7 & 13.7 & 15.6 & 54000 & 28 \\
\hline Middle & 4.4 & 24 & 2.4 & 2.3 & 2.5 & 3.8 & 13.4 & 16.8 & 44000 & 30 \\
\hline Outlet & 4 & 24 & 2.6 & 2.4 & 2.3 & 4.0 & 13 & 16.9 & 40000 & 29.2 \\
\hline Changes (\%) & -20.0 & 4.3 & 13.0 & 14.3 & -39.5 & 8.1 & -5.1 & 8.3 & -25.9 & 4.3 \\
\hline Guidelines* & & & & & 2 & 6 & 30 & - & 250 & 0.5 \\
\hline
\end{tabular}

*MEP (2002): Ministry of Environmental Protection, China.

Table 2. Heavy metals concentrations $(\mathrm{mg} / \mathrm{l})$ in the wastewater samples collected from reservoir (average values for winter and summer).

\begin{tabular}{|l|c|c|c|c|c|c|c|}
\hline \multicolumn{1}{|c|}{ Location } & Cd & Cr & Cu & Fe & Mn & Ni & Zn \\
\hline Inlet & 0.5 & 0.9 & 18.6 & 55.7 & 30.8 & 1.8 & 9.4 \\
Middle & 0.3 & 0.8 & 15.4 & 50.2 & 27.3 & 1.4 & 7.9 \\
Outlet & 0.2 & 0.5 & 14.5 & 49.6 & 25.5 & 1.3 & 7.4 \\
Changes (\%) & -60.0 & -44.4 & -22.0 & -11.0 & -17.2 & -27.8 & -21.3 \\
Guidelines* & 0.005 & 0.05 & 1 & 0.3 & 0.1 & 0.02 & 2.0 \\
\hline
\end{tabular}

*MEP (2002): Ministry of Environmental Protection, China.

observed from inlet to outlet of the reservoir. This enhancement in $\mathrm{pH}$ is very conducive to the development of the ecological community in the wastewater which in turn further increases the $\mathrm{pH}$ of wastewater as reported by Chen et al. (2008).

The DO values in winter were higher than those in the summer. In addition the samples of outlet have been observed to display lower $(P<0.05)$ values compared with the inlet of the CMWR. Other chemical parameters are not significantly affected by the seasonal changes in temperature. Like DO, COD values also depreciate from inlet to outlet but the overall reduction is insignificant $(\mathrm{P}<$ $0.05)$. The BOD values depict a picayune enhancement $(P<0.05)$ from inlet to outlet. However, the decrement in DO $(39.5 \%)$ is associated with the increment in BOD values from inlet to outlet of the CMWR. The depletion of DO may account for the more anoxic nature of the aquatic ecosystem environment. This kind of environment would likely support a community of anaerobic bacteria, which have a competitive advantage over strict aerobes and anaerobes under conditions of varying DO concentrations (Foster et al., 2008).

In the wastewater samples, the increase in DOC can lead to an enhancement in the BOD values in the aquatic system which may further result in the DO reduction as observed in this study. The findings of this study are in contradiction with those reported previously by Foster et al. (2008). The $\mathrm{SO}_{4}{ }^{2-}$ and sulfide concentrations have also been estimated in the samples of CMWR. The $\mathrm{SO}_{4}{ }^{2-}$ concentrations are extremely higher than the permissible limit targeted for industrial and agricultural uses (MEP, 2002). The value for $\mathrm{SO}_{4}{ }^{2-}$ concentrations is significantly smaller $(P<0.05)$ in the outlet sample compared to that in the inlet ones. The decrease in $\mathrm{SO}_{4}{ }^{2-}$ value may be related to its reduction into sulfides (Foucher et al., 2001; Luptakova and Kusnierova, 2005).

Table 3 depicts the Pearson's correlations data of different parameters evaluated for the wastewater. The results indicate a strong negative correlation for $\mathrm{pH}$ with $\mathrm{DO}, \mathrm{SO}_{4}{ }^{2-}$ and $\mathrm{COD}$, while a strong positive correlation has been observed for $\mathrm{pH}$ with DOC, BOD, and sulfides. Similarly, a strong positive correlation is recognized for $\mathrm{DO}$ with $\mathrm{SO}_{4}{ }^{2-}$ and $\mathrm{COD}$ and a strong negative correlation is noticed for DO with DOC, BOD, and sulfides. A strong negative correlation has been perceived between DOC and $C O D$ with a strong positive correlation between DOC and BOD.

\section{Heavy metals}

Table 2 summarizes the heavy metal concentrations in 
the wastewater samples collected from inlet, middle, and outlet of CMWR. Cd concentrations significantly decrease $(P<0.01)$ with an increase in the distance from inlet to outlet of the CMWR. The data of the present study are not in agreement with those reported by Milu et al. (2002) but consistent with those observed by Foster et al. (2008). The $60 \%$ decrease in $\mathrm{Cd}$ concentrations from inlet to outlet of the CMWR implies that the impounding of $\mathrm{CM}$ Islam-ud-din et al.

7895

Table 3. Pearson correlations among different parameters in wastewater samples collected from CMWR.

\begin{tabular}{|c|c|c|c|c|c|c|c|c|c|c|c|c|c|c|}
\hline \begin{tabular}{|l|} 
Parameter \\
\end{tabular} & $\mathrm{pH}$ & DO & SO42- & DOC & COD & BOD & Sulfides & Cd & $\mathrm{Cr}$ & $\mathrm{Cu}$ & $\mathrm{Fe}$ & $\mathrm{Mn}$ & $\mathrm{Ni}$ & $\mathrm{Zn}$ \\
\hline $\mathrm{pH}$ & 1 & -0.978 & $-0.999^{*}$ & 0.965 & -0.963 & 0.929 & 0.737 & $-1.000^{\star *}$ & -0.891 & -0.992 & -0.970 & $-1.000^{\star *}$ & -0.990 & -0.996 \\
\hline DO & & 1 & 0.985 & $-.999^{*}$ & 0.886 & -0.831 & -0.862 & 0.978 & 0.777 & 0.996 & $0.999^{*}$ & 0.976 & $0.998^{*}$ & 0.993 \\
\hline $\mathrm{SO}_{4}{ }^{2-}$ & & & 1 & -.974 & 0.953 & -0.914 & -0.761 & $0.999^{*}$ & 0.874 & 0.996 & 0.979 & $0.999^{*}$ & 0.994 & $0.999^{*}$ \\
\hline DOC & & & & 1 & -0.859 & 0.799 & 0.888 & -0.965 & -0.742 & -0.990 & $-1.000^{*}$ & -0.963 & -0.993 & -0.985 \\
\hline COD & & & & & 1 & -0.994 & -0.528 & 0.963 & 0.980 & 0.923 & 0.870 & 0.965 & 0.915 & 0.935 \\
\hline BOD & & & & & & 1 & 0.434 & -0.929 & -0.996 & -0.876 & -0.811 & -0.931 & -0.866 & -0.891 \\
\hline Sulfides & & & & & & & 1 & -0.737 & -0.350 & -0.814 & -0.879 & -0.732 & -0.826 & -0.795 \\
\hline $\mathrm{Cd}$ & & & & & & & & 1 & 0.891 & 0.992 & 0.970 & $1.000^{* *}$ & 0.990 & 0.996 \\
\hline $\mathrm{Cr}$ & & & & & & & & & 1 & 0.829 & 0.755 & 0.894 & 0.817 & 0.846 \\
\hline $\mathrm{Cu}$ & & & & & & & & & & 1 & 0.993 & 0.992 & $1.000^{*}$ & $0.999^{*}$ \\
\hline $\mathrm{Fe}$ & & & & & & & & & & & 1 & 0.969 & 0.995 & 0.988 \\
\hline $\mathrm{Mn}$ & & & & & & & & & & & & 1 & 0.989 & 0.995 \\
\hline $\mathrm{Ni}$ & & & & & & & & & & & & & 1 & $0.999^{*}$ \\
\hline $\mathrm{Zn}$ & & & & & & & & & & & & & & 1 \\
\hline
\end{tabular}

${ }^{*}$ Correlation is significant at the 0.05 level (2-tailed). ${ }^{* *}$ Correlation is significant at the 0.01 level (2-tailed).

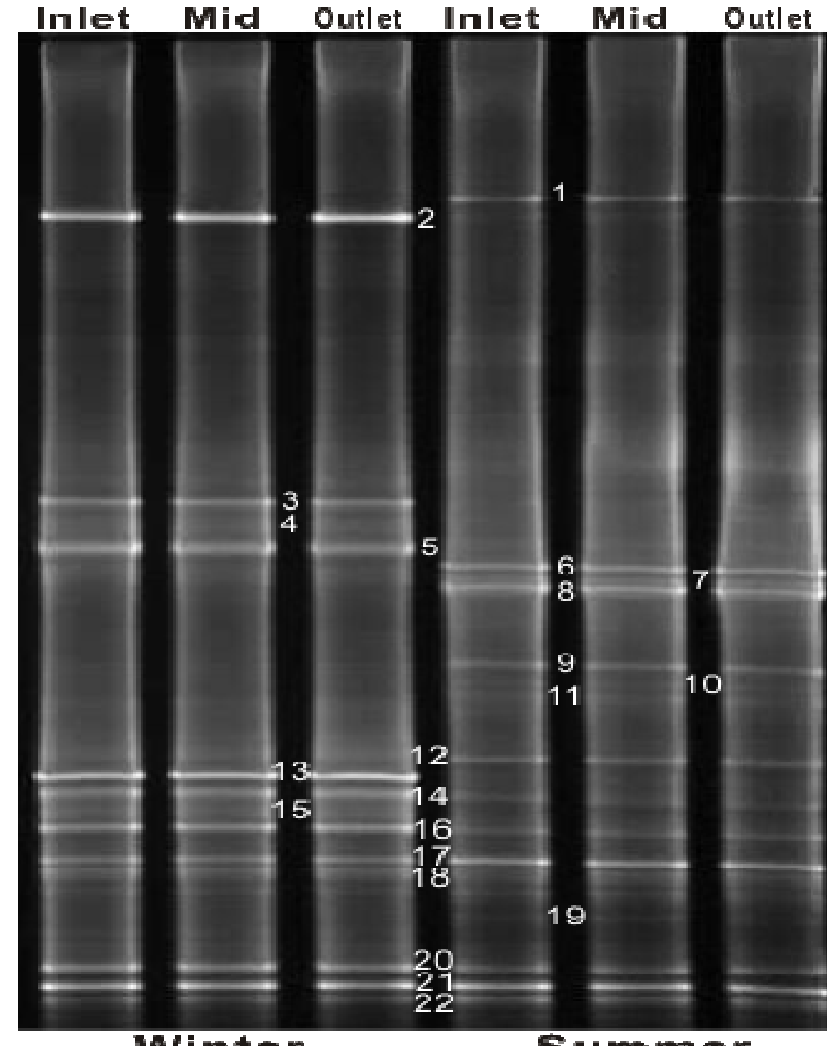

Winter

Summer

Figure 1. Banding patterns generated by PCR-DGGE of $16 \mathrm{~S}$ rRNA fragments collected from wastewater samples. wastewater has significantly reduced the contents of $\mathrm{Cd}$. Like $\mathrm{Cd}, \mathrm{Cr}$ concentrations decrease with increasing distance from the inlet to outlet. Typically, the $\mathrm{Cr}$ contents can significantly be minimized by impounding of $\mathrm{CM}$ wastewater. The data regarding $\mathrm{Cu}$ concentrations also contradict with those reported by Salvarredy-Aranguren et al. (2008) and Yin et al. (2008). However, the decrease in $\mathrm{Cu}$ concentration indicates that the impounding of $\mathrm{CM}$ wastewater can minimize the $\mathrm{Cu}$ contents. The $\mathrm{Fe}$ concentrations estimated in this study are significantly smaller than those reported by Yin et al. (2008). The Fe concentrations also demonstrate a trifling depreciation ( $P$ $<0.05$ ) with increase in distance.

Like $\mathrm{Fe}$ and $\mathrm{Cu}$, the concentrations of $\mathrm{Mn}$ are not significantly $(\mathrm{P}<0.05)$ lower in the inlet samples as compared to that in the outlet one. However, the decrease in $\mathrm{Mn}$ concentrations from inlet to outlet is higher than $\mathrm{Fe}$ concentrations in the CMWR. An insignificant decrease in the concentrations of $\mathrm{Ni}(\mathrm{P}<0.05)$ is observed with an increase in the distance from inlet to outlet. However, the concentrations of $\mathrm{Zn}$ in the sample of outlet is not significantly lower $(P<0.05)$ compared to that of the inlet of the CMWR. As the distance is increased from the inlet, $\mathrm{Zn}$ concentrations are decreased. It means that the impounding of $\mathrm{CM}$ wastewater may aid also in the minimization of $\mathrm{Zn}$ contents. In a word, the decrease in concentrations of selected heavy metals is found in the order of $\mathrm{Cd}>\mathrm{Cr}>\mathrm{Ni}>\mathrm{Cu}>\mathrm{Zn}>\mathrm{Mn}>\mathrm{Fe}$. This decrease in heavy metal concentrations in the CMWR may be attributed to the 
settling and precipitation. Removal of heavy metals from aqueous media takes place through several methods but settling/precipitation is one of the most essential techniques used for the minimization of heavy metals in wastewater. Settling is a simpler, efficient, and relatively cost effective process for the separation of heavy metals from mining wastewater (Feng et al. 2004).

$7896 \quad$ Afr. J. Biotechnol.

Table 4 Identification and classification of 16S rRNA gene sequences detected in the CMWR by culture independent methods.

\begin{tabular}{|l|c|l|c|l|}
\hline Taxon & $\begin{array}{c}\text { Number of } \\
\text { DGGE Bands }\end{array}$ & $\begin{array}{c}\text { Accession } \\
\text { number }\end{array}$ & $\begin{array}{c}\text { Similarity } \\
(\%)\end{array}$ & \multicolumn{1}{|c|}{ Most closely related bacterial sequence } \\
\hline Proteobacteria; & 3 & GU979831 & 99 & Rheinheimera sp. G3DM-27 EU037278 \\
Gammaproteobacteria & 2 & GU979830 & 100 & Rheinheimera sp. WMF-1 AM690025 \\
& 11 & GU979839 & 98 & Rheinheimera sp. G3DM-27 EU037278 \\
& 15 & GU979843 & 99 & Rheinheimera sp. WMF-1 AM690025 \\
& 20 & GU979836 & 97 & Uncultured Rheinheimera sp.clone AM911042 \\
& 14 & GU979848 & 99 & Acidithiobacillus ferrooxidans GU168004 \\
& 7 & GU979842 & 95 & Acidithiobacillus ferrooxidans strain S1 FJ913262 \\
& 17 & GU979845 & 95 & Gamma proteobacterium QLW-Oulin5D AM182267 \\
& 10 & GU979838 & 99 & Ancultured gamma proteobacterium clone Blsi9 J318178 \\
\hline Proteobacteria; & 21 & GU979849 & 99 & Alpha proteobacterium SK50-29 AB231998 \\
Alphaproteobacteria & 22 & GU979850 & 100 & Bradyrhizobiaceae bacterium NS1 EU177513 \\
& 5 & GU979833 & 99 & Uncultured Sphingomonadaceae bacterium clone 516865 \\
\hline Betaproteobacteria; & 6 & GU979834 & 98 & Burkholderia sp. kmd_430 EU723175 \\
Burkholderiaceae & 1 & GU979829 & 95 & Uncultured bacterium clone CRP99-67 AF428721 \\
\hline Unclassifiable & 4 & GU979832 & 94 & Uncultured bacterium clone 5C231280 EU803675 \\
& 9 & GU979837 & 94 & Uncultured bacterium clone Elev_16S_1189 EF019837 \\
& 12 & GU979840 & 95 & Uncultured bacterium clone J-3FACA42 DQ394862 \\
& 13 & GU979841 & 96 & Uncultured bacterium clone RA13C21 AF407401 \\
& 16 & GU979844 & 99 & Uncultured Acidobacteria bacterium AY690035 \\
& 18 & GU979846 & 98 & Uncultured bacterium clone YSK16S-34 EF612997 \\
& 19 & GU979847 & 99 & Uncultured bacterium clone DCN-I-29 DQ660852 \\
\hline
\end{tabular}

Table 3 displays the Pearson's correlations data of heavy metals with other parameters investigated in the wastewater. The relationship values between $\mathrm{pH}$ and heavy metals range from -0.891 to -1.000 , indicating a strong negative correlation between $\mathrm{pH}$ and heavy metals. The acidic nature (low $\mathrm{pH}$ ) of $\mathrm{CM}$ wastewater can increase the solubility of metals in water. However, a strong positive correlation, ranged over $0.777-0.999$ and $0.807-1.000$ is observed for heavy metals with DO and $\mathrm{SO}_{4}{ }^{2-}$, respectively. A strong negative correlation ranging from -0.742 to -1.000 and from -0.866 to -0.996 is noticed for heavy metals with $\mathrm{DOC}$ and $\mathrm{BOD}$, respectively. However, a strong positive correlation is found between heavy metals and COD and its values range from 0.870 to 0.980 .

\section{Bacterial diversity}

Figure 1 shows the DGGE profiles of 16S rRNA gene fragments obtained from water samples collected in winter and summer from CMWR. In this study, the DGGE profiles reveal some variations in the banding patterns of the samples collected in two different seasons resulting in a modification in the bacterial community structure associated with the seasonal change of temperature. On the other hand, the same banding patterns for sample scollected from different points of the reservoir indicated no major changes in the bacterial community structure in all the samples collected from inlet, middle and outlet. The majority of bands are almost evenly localized, and more bands appear in the lower parts of the gel under higher denaturing conditions.

The samples collected in December exhibit fewer bands than those of May. This may be ascribed to the change in water temperatures. There are 10 common bands (bands number; 2, 5, 12, 14, 16, 17, 18, 20, 21 and 22) in both the seasonal samples. In this study, the DGGE profiles also demonstrate the similar banding pattern in the samples of different locations attributed to the plasticity of bacteria in CMWR. Phylogenetic tree of the cloning sequences obtained for all DGGE bands 
indicate that the bacterial community is divided into different taxonomic groups, and among which Rheinheimera sp., At. ferrooxidans, Afipia sp. and Burkholderia sp. are the most dominant species besides some other bacteria such as uncultured bacterium clones (Table 4 and Figure 2). Similar bacterial species are also reported in the literature (Xiao et al., 2009). In this study, about $20 \%$ clone sequences have shown similarity (98- 


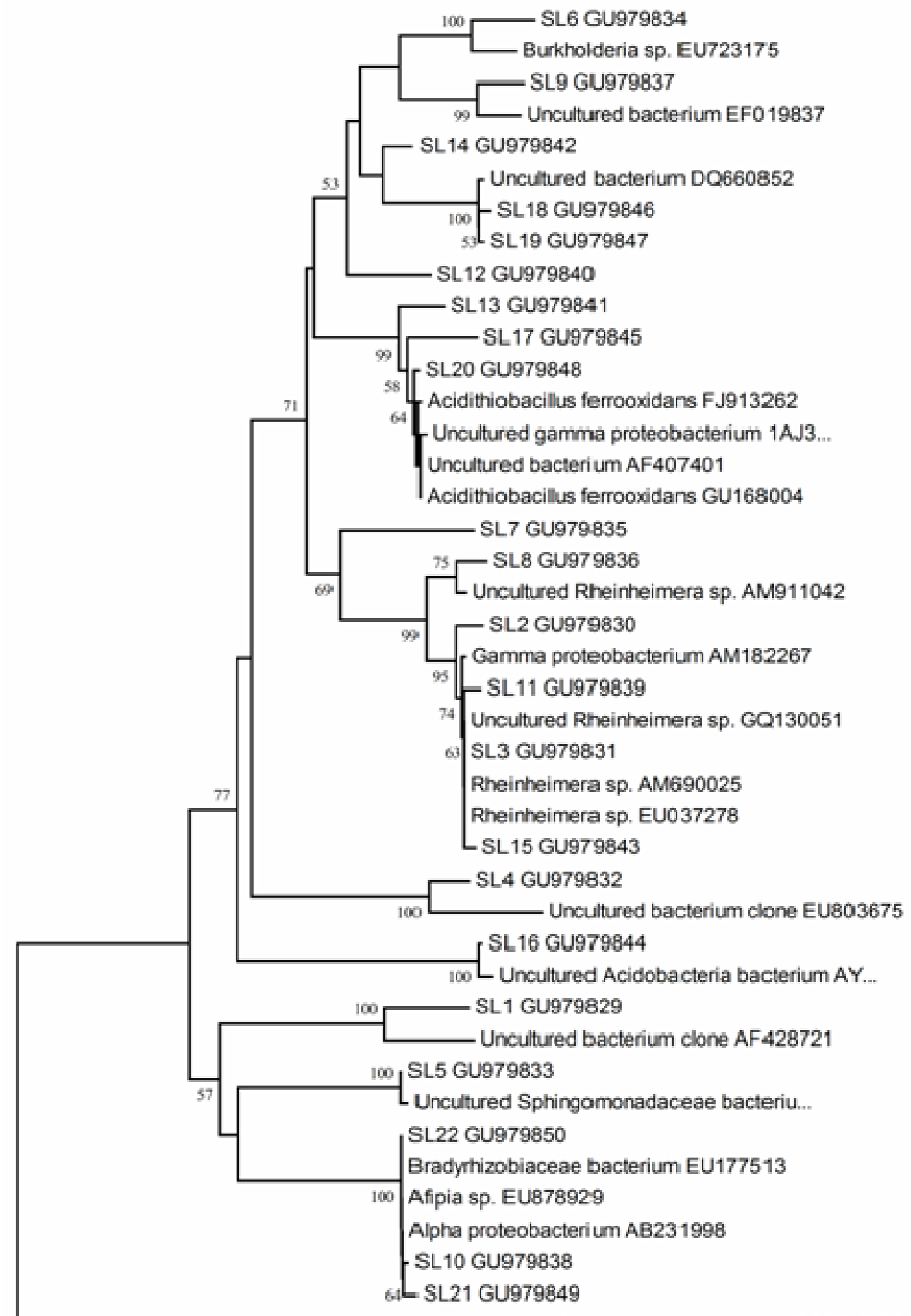

- Methanothermobacter sp. THUT3(DQ683581)

$$
\stackrel{0.02}{\longmapsto}
$$

Figure 2. Phylogenetic relationships of representative bacterial cloned DGGE gel band 16S rRNA gene sequences as determined by the neighbor-joining method. Methanothermobacteria sp. (DQ683581) was used as the out-group. Bootstrap values of $>50 \%$ (obtained with 1000 resembling) are shown at nodes. The source of sequences was shown in the parenthesis. The reference sequences are obtained from GenBank. 
$100 \%$ ) with Rheinheimera sp., $10 \%$ with A. ferrooxidans, $10 \%$ with Gamma proteobacterium, 5\% with each of Afipia sp., Burkholderia sp., Alpha proteobacterium and Bradyrhizobiaceae bacterium. The remaining $40 \%$ is observed to be uncultured bacterial clones. The Afipia sp. and Burkholderia sp. are found in summer samples only while the most of the other species are common in both the seasonal samples and ubiquitous at all the sites. The mentioned proportions remain significantly $(P=0.05)$ unaltered between the samples of inlet, middle and outlet of the CMWR. Hence, most of the chemical parameters are not significantly changed by the seasonal variation except water temperature, $\mathrm{pH}$, and $\mathrm{DO}$ which may be ascribed to the changes in bacterial diversity in the two types of seasonal water samples.

Like this study, the acidophilic bacteria have also been reported in CM water and soil by numerous researchers in the past, which play an important role in environmental ecosystem and the biotechnological processes (Hallberg and Johnson, 2001; He et al., 2007; Xiao et al., 2009). A. ferrooxidans is a chemolithoautotrophic gram-negative bacterium that derives energy and electrons from the oxidation of ferrous iron or sulfur and various reduced sulfur compounds at low $\mathrm{pH}$ (2) by using oxygen as the electron acceptor. Being an autotrophic organism, $A$. ferrooxidans fixes $\mathrm{CO}_{2}$ and $\mathrm{N}$ under different schemes such as Calvin-Bassham-Benson scheme and microaerophilic conditions, respectively. According to Ohmura et al. (1999) and Drobner et al. (1990), A. ferrooxidans are able to grow on hydrogen as an energy source both aerobically and anaerobically by the dissimilatory reduction of $\mathrm{Fe}$ (III). Previously, it is reported that $A$. ferrooxidans is active in the solubilization of $\mathrm{Cu}$ and in the processing of refractory gold ores in bioleaching operations and is also a contributor to acid mine drainage (Levicán et al., 2002).

However, Afipia sp. belongs to alpha-proteobacteria usually present in oligotrophic conditions and isolated from different environmental samples. Previously, the Afipia sp. has also been reported from the membrane of drinking water treatment (Chon et al., 2009). Like $A$. ferrooxidans, Rheinheimera sp. belongs to gammaprotobacteria and it is gram-negative and anaerobic in nature. Rheinheimera sp. utilizes different carbon sources and gives positive tests for starch and gelatin hydrolysis and nitrate reduction along with oxidase and catalase as the major activities (Merchant et al., 2007). Like other bacteria, the Rheinheimera sp. has also been isolated from different environmental samples including seawater (Yoon et al., 2007) and freshwater (Merchant et al., 2007). The Burkholderia (previously part of Pseudomonas) genus name refers to a group of virtually ubiquitous gram-negative, motile, obligately aerobic rod-shaped bacteria. It includes both animal/human and plant pathogens as well as many species having the potential for agricultural or environmental purposes, such as biolo- gical control, bioremediation, atmospheric nitrogen fixation and plant growth stimulation (Salles et al., 2004). It belongs to Betaproteobacteria and comprises over 30 species (Coenye and Vandamme, 2003). Characteristically, the CM wastewater has limited nutrients but also enriched in the bacterial diversity. Similar results have also been reported by Bunce et al. (2001).

\section{Conclusions}

Wastewater of Copper mining is highly contaminated with different pollutants and the most of the chemical parameters are little influenced by the seasonal changes in water temperature. However, the impounding of wastewater has brought about significant alterations in the selected parameters. The most of the parameters are found well beyond the permissible limits set by MEPChina. However, the PCR-DGGE followed by the subsequent cloning approach reveals that the bacterial community diversity is rich. In addition, Rheinheimera sp., A. ferrooxidans, Afipia sp. and Burkholderia sp. are the dominant species in the CMWR. It is also evident that the seasonal changes in the water temperature lead to some variations in $\mathrm{pH}$ and $\mathrm{DO}$ contents of the water which further in turn results in the modification of the bacterial diversity.

\section{REFERENCES}

APHA (American Public Health Association), AWWA (American Water Works Association), and WEF (Water Environment Federation) (1998). Standard methods for the examination of water and wastewater (20th ed.). Washington DC, USA.

Bunce NJ, Chartrand M, Keech P (2001). Electrochemical treatment of acidic aqueous ferrous sulfate and copper sulfate as models for acid mine drainage. Water Res. 35: 4410-4416.

Chen YQ, Ren GJ, An SQ, Sun QY, Liu CH, Shuang JL (2008). Changes of bacterial community structure in copper mine tailings after colonization of reed (Phragmites communis). Pedosphere, 18: 731-740.

Chon K, Chon K, Chang JS, Oh H, Lee E, Cho J (2009). Technical note: Community of bacteria attached on the PVDF MF membrane surface fouled from drinking water treatment, in Seoul, Korea. Drink-water-eng-sci 2: 35-39.

Coenye T, Vandamme P (2003). Diversity and significance of Burkholderia species occupying diverse ecological niches. Environ. Microbiol. 5: 719-729.

Compton JE, Watrud LS, Arlene Porteous L and DeGrood S (2004). Response of soil microbial biomass and community composition to chronic nitrogen additions at Harvard forest. Forest Ecol. Manage. 196: 143-158.

DeLong EF (1992). Archaea in coastal marine environments. Proc. Natl. Acad. Sci. USA. 89: 5685-5685.

Drobner E, Huber H, Stetter KO (1990). Thiobacillus ferrooxidans, a facultative hydrogen oxidizer. Appl. Environ. Microbiol. 56: 29222923.

Ehlers G, Rose P (2005). Preliminary evaluation of a White-Rot Fungal Reactor in the treatment of a waste oil-recycling wastewater. Bioremediat. J. 9: 21-32.

Feng D, Van Deventer JSJ, Aldrich C (2004). Removal of pollutants from acid mine wastewater using metallurgical by-product slags. 
Sep.

Purif. Technol. 40: 61-67.

Feris KP, Ramsey PW, Rillig M, Moore JN, Gannon JE, Holben WE (2004). Determining rates of change and evaluating group-level resiliency differences in hyporheic microbial communities in response to fluvial heavy-metal deposition. Appl. Environ. Microbiol. 70: 4756-4765.

Fey A, Conrad R (2000). Effect of temperature on carbon and electron flow and on the archaeal community in methanogenic rice field soil. Appl. Environ. Microbiol. 66: 4790-4797.

Foster AL, Munk L, Koski RA, Shanks WC, Stillings LL (2008). Relationships between microbial communities and environmental parameters at sites impacted by mining of volcanogenic massive sulfide deposits, prince william sound, alaska. Appl. Geochem. 23: 279-307.

Foucher S, Battaglia-Brunet F, Ignatiadis I, Morin D (2001). Treatment by sulfate-reducing bacteria of Chessy acid-mine drainage and metals recovery. Chem. Eng. Sci. 56: 1639-1645

Guo Z, Megharaj M, Beer M, Ming H, Mahmudur Rahman M, Wu W, Naidu R (2009). Heavy metal impact on bacterial biomass based on DNA analyses and uptake by wild plants in the abandoned copper mine soils. Bioresour. Technol. 100: 3831-3836.

Hallberg KB, Johnson BD (2001). Biodiversity of acidophilic prokaryotes. In: Laskin A, Bennett JW, Gadd G (eds). Adv. Appl. Microbiol. Academic Press. pp. 37-84.

He Z, Xiao S, Xie X, Zhong H, Hu Y, Li Q, Gao F, Li G, Liu J, Qiu G (2007). Molecular diversity of microbial community in acid mine drainages of Yunfu sulfide mine. Extremophiles, 11: 305-314.

Khan S, Cao Q, Hesham A E-L, Xia Y, He JZ (2007). Soil enzymatic activities and microbial community structure with different application rates of $\mathrm{Cd}$ and $\mathrm{Pb}$. J. Environ. Sci-China. 19: 834840.

Khan S, Cao Q, Zheng YM, Huang YZ, Zhu YG (2008). Health risks of heavy metals in contaminated soils and food crops irrigated with wastewater in Beijing, China. Environ. Pollut. 152: 686-692.

Kopke B, Wilms R, Engelen B, Cypionka H, Sass H (2005). Microbial diversity in coastal subsurface sediments: A cultivation approach using various electron acceptors and substrate gradients. Appl.

Environ. Microbiol. 71: 7819-7830.

Levicán G, Bruscella P, Guacunano M, Inostroza C, Bonnefoy V, Holmes DS, Jedlicki E (2002). Characterization of the peti and res operons of Acidithiobacillus ferrooxidans. J. Bacteriol. 184: 1498-1498.

Liu CP, Sheu BH (2003). Dissolved organic carbon in precipitation, throughfall, stemflow, soil solution and stream water at the Guandaushi subtropical forest in Taiwan. Forest Ecol. Manage. 172: 315-325.

Luptakova A, Kusnierova M (2005). Bioremediation of acid mine drainage contaminated by SRB. Hydrometallurgy, 77: 97-102.

Malik S, Beer M, Megharaj M, Naidu R (2008). The use of molecular techniques to characterize the microbial communities in contaminated soil and water. Environ. Int. 34: 265-276.

MEP (2002). Environmental quality standard for surface water. GB 3838-2002, Ministry of Environmental Protection, PR China.

Merchant MM, Welsh AK, McLean RJC (2007). Rheinheimera texasensis sp. Nov., a halointolerant freshwater oligotroph. Int. J. Syst. Evol. Microb. 57: 2376-2380.
Milu V, Leroy J, Peiffert C (2002). Water contamination downstream from a copper mine in the Apuseni Mountains, Romania. Environ. Geol. 42: 773-782.

Muhling M, Woolven-Allen J, Murrell JC. Joint I (2008). Improved groupspecific PCR primers for denaturing gradient gel electrophoresis analysis of the genetic diversity of complex microbial communities. ISME J. 2: 379-392.

Muyzer G, De Waal EC, Uitterlinden AG (1993). Profiling of complex microbial populations by denaturing gradient gel electrophoresis analysis of polymerase chain reaction-amplified genes coding for 16S rRNA. Appl. Environ. Microbiol. 59: 695-700.

Muyzer G, Hottentrager S, Teske AP, Wawer C (1995). Denaturing gradient gel electrophoresis of PCR-amplified 16S rDNA: A new molecular approach to analyse the genetic diversity of mixed microbial communities. In: (Akkermans ADL, van Elsas JD, de Bruijn FJ (ed.). Molecular Microbial Ecology Manual. Dordrecht, the Netherlands: Kluwer Acad. pp. 1-23.

Ohmura N, Matsumoto N, Sasaki K, Nagaoka T, Saiki H (1999). Growth of Thiobacillus ferrooxidans on hydrogen by the dissimilatory reduction of ferric iron under anaerobic conditions. In: (Amils $R$ and Ballester A (ed.). Biohydrometallurgy and the environment: Toward the mining of the 21st century. Amsterdam, The Netherlands: Elsevier. pp. 767-775.

Passariello B, Giuliano V, Quaresima S, Barbaro M, Caroli S, Forte G, Carelli G, lavicoli I (2002). Evaluation of the environmental contamination at an abandoned mining site. Microchem. J. 73: 245-250.

Salles JF, Van Veen JA, Van Elsas JD (2004). Multivariate analyses of Burkholderia species in soil: Effect of crop and land use history. Appl. Environ. Microbiol. 70: 4012-4012.

Salvarredy-Aranguren MM, Probst A, Roulet M, Isaure MP (2008). Contamination of surface waters by mining wastes in the Milluni Valley (Cordillera Real, Bolivia): Mineralogical and hydrological influences. Appl. Geochem. 23: 1299-1324.

Wang Q, Zhou D, Cang L, Li L, Zhu H (2009). Indication of soil heavy metal pollution with earthworms and soil microbial biomass carbon in the vicinity of an abandoned copper mine in Eastern Nanjing, China. Eur. J. Soil Biol. 45: 229-234.

Xiao S, Xie X, Liu J (2009). Microbial communities in acid water environments of two mines, China. Environ. Pollut. 157: 10451050.

Yin H, Cao L, Qiu G, Wang D, Kellogg L, Zhou J, Liu X, Dai Z, Ding J, Liu X (2008). Molecular diversity of $16 \mathrm{~S}$ rRNA and gyrB genes in copper mines. Arch. Microbiol. 189: 101-110.

Yoon JH, Park SE, Kang SJ, Oh TK (2007). Rheinheimera aquimaris sp. Nov., isolated from seawater of the East Sea in Korea. Int. J. Syst. Evol. Microb. 57: 1386-1390.

Yu Z, Morrison M (2004). Comparisons of different hypervariable regions of rrs genes for use in fingerprinting of microbial communities by PCR-Denaturing Gradient Gel Electrophoresis. Appl. Environ. Microbiol. 70: 4800-4800.

Zhou J, Xia B, Treves DS, Wu LY, Marsh TL, O'Neill RV, Palumbo AV, Tiedje JM (2002). Spatial and resource factors influencing high microbial diversity in soil. Appl. Environ. Microbiol. 68: 326-334. 